bryg. dr n. med. Mariusz Chomoncik ${ }^{\mathrm{a}, \mathrm{b}) \star}$, bryg. dr inż. Mariusz Feltynowski ${ }^{()}$, bryg. lek. Leszek Smolarczyk ${ }^{\mathrm{d})}$

\author{
a) Szkoła Aspirantów PSP w Krakowie/College of the State Fire Service in Kraków \\ b) Państwowa Wyższa Szkoła Zawodowa w Nowym Sączu/State Higher Vocational School in Nowy Sącz \\ c) Centrum Naukowo Badawcze Ochrony Przeciwpożarowej - Państwowy Instytut Badawczy / Scientific and Research Centre \\ for Fire Protection - National Research Institute \\ d) Komenda Gtówna PSP/State Fire Service Headquarters \\ *Autor korespondencyjny/Corresponding author: mchomoncik@sapsp.pl
}

\title{
Działania ratownicze komponentu medycznego Polskiej Ciężkiej Grupy \\ Poszukiwawczo-Ratowniczej (HUSAR Poland) podczas akcji po trzęsieniu ziemi w Nepalu w roku 2015
}

\author{
Rescue Operations of the Medical Component of the Polish Heavy Urban Search \\ and Rescue Unit (HUSAR Poland) During the Mission After the 2015 Earthquake in Nepal \\ Спасательные операции медицинского подразделения польской тяжелой \\ поисково-спасательной группы (HUSAR Польша) во время акции после землетрясения \\ в Непале в 2015 году
}

\begin{abstract}
ABSTRAKT
Cel: Autorzy artykułu, uczestnicy akcji Ciężkiej Grupy Poszukiwawczo-Ratowniczej Państwowej Straży Pożarnej (HUSAR Poland) po trzęsieniu ziemi w Nepalu w 2015 r. na podstawie prezentowanego studium przypadku dokonali próby przybliżenia czytelnikom specyfiki działań komponentu medycznego tej specjalistycznej formacji.

Wprowadzenie: We wstępie wyliczono główne jednostki organizacyjne PSP, z których pochodzą ratownicy Grupy, doprecyzowano okoliczności jej formalnego utworzenia, w tym powołanie pierwszego Zespołu Komendanta Głównego PSP ds. specjalizacji poszukiwawczo-ratowniczej. Następnie opisano rolę ustandaryzowanych zasad poszukiwawczo-ratowniczych w Krajowym Systemie Ratowniczo-Gaśniczym oraz przedstawiono dotychczasowe międzynarodowe akcje po trzęsieniach ziemi, w których brali udział polscy strażacy. Następnie, po wyjaśnieniu mandatu prawnego Międzynarodowej Grupy Doradczej ds. Poszukiwań i Ratownictwa (INSARAG) oraz roli jej wytycznych w określaniu minimalnych międzynarodowych standardów, autorzy doprecyzowali skład wszystkich komponentów HUSAR Poland. Celem badań było znalezienie odpowiedzi na pytanie dotyczące optymalnego sposobu wykorzystania potencjału komponentu medycznego HUSAR Poland podczas zagranicznych akcji poszukiwawczo-ratowniczych.

Metody: Materiał badawczy stanowiły międzynarodowe i krajowe dokumenty normatywne regulujące zasady funkcjonowania HUSAR Poland i określające minimalne standardy dla grup poszukiwawczo-ratowniczych i zagranicznych zespołów medycznych. Wykorzystano analizę akcji HUSAR Poland w Nepalu w 2015 r. oraz wnioski z akcji na Haiti w 2010 r. Główną metodą badawczą była analiza dokumentów oraz statystyk. W tekście przekrojowo przedstawiono zadania komponentu medycznego USAR Poland w różnych fazach tzw. „cyklu misji” i używane w praktyce dokumenty. Szczególną uwagę, zgodnie z tytułem artykułu, poświęcono ukazaniu zadań medycznych zrealizowanych podczas akcji w Nepalu. Autorzy nie tylko przedstawili przykładowe statystyki z działań komponentu medycznego Grupy w Nepalu, ale odnieśli się też do zakresu analogicznych działań z akcji na Haiti w 2010 r.

Podsumowanie: W podsumowaniu i wnioskach autorzy podjęli się próby wskazania najefektywniejszego wykorzystania komponentu medycznego HUSAR Poland w działaniach międzynarodowych, tuż po zakończeniu fazy poszukiwawczo-ratowniczej związanej z wydobywaniem poszkodowanych spod gruzów (tzw. koncepcja działania poza gruzami), tak aby jego możliwości były wykorzystane optymalnie i w pełni komplementarnie do oczekiwań społeczności poszkodowanej oraz zarządzających katastrofą instytucji. Sformułowano wnioski, zgodnie z którymi sugerowaną rolą mogłaby być realizacja zadań zbieżnych do przewidzianych wg Światowej Organizacji Zdrowia dla zagranicznego zespołu medycznego typu pierwszego „Foreign Medical Team type 1".

Słowa kluczowe: INSARAG, HUSAR POLAND, ratownictwo, zespół medyczny, Nepal, trzęsienie ziemi

Typ artykułu: studium przypadku
\end{abstract}

Przyjęty: 14.05.2018; Zrecenzowany: 27.06.2018; Zatwierdzony: 05.11.2018;

Autorzy wnieśli równy wkład merytoryczny w opracowanie artykułu;

Identyfikatory ORCID autorów: M. Chomoncik - 0000-0002-2535-488X; M. Feltynowski - 0000-0001-5614-8387; L. Smolarczyk - 0000-0002-9028-0485; Proszę cytować: BiTP Vol. 51 Issue 3, 2018, pp. 104-118, doi: 10.12845/bitp.51.3.2018.7;

Artykuł udostępniany na licencji CC BY-SA 4.0 (https://creativecommons.org/licenses/by-sa/4.0/). 


\section{ABSTRACT}

Purpose: Based on a case study, the authors, members of a heavy urban search and rescue unit (HUSAR Poland) of the State Fire Service (SFS), who participated in relief operations in the aftermath of the 2015 Nepal earthquake, try to describe the roles of medical teams within this specialist organisation. Introduction: The article starts by enumerating the key organisational bodies of the State Fire Service where the Unit's members normally work, and proceeds to outline the history of its formal establishment, including the appointment of the first SFS Chief Commander Team for Search \& Rescue. Then it describes the role of the uniform search and rescue procedures within the State Rescue and Fire-Fighting System, and presents previous international operations following earthquakes, in which Polish firefighters participated. Finally, the paper explains the legal basis for the International Search and Rescue Advisory Group (INSARAG) and the importance of its guidelines for specifying minimum international standards, and lists all the components of HUSAR Poland. The purpose of this paper was to address the question concerning the best way to utilise the potential of HUSAR Poland's medical component during foreign search \& rescue operations.

Methods: Research material comprised international and domestic standards which govern the functioning of HUSAR Poland and which define the minimum standards for search and rescue groups and foreign medical teams. The paper analyses HUSAR Poland's involvement in the 2015 Nepal operation, and conclusions drawn from the 2010 Haiti operation. Its primary research method was the analysis of documents and statistical data. The article provides an overview of USAR Poland's medical team at different phases of the Response Cycle, and documents used in practice. As shown in the title, special attention was given to describing medical roles and responsibilities fulfilled during the Nepal operation. The authors not only present some statistical examples for the Unit's medical team involvement in Nepal, but also refer to some similar activities carried out during the 2010 Haiti operation. Summary: In the Summary and conclusions section, the authors tried to identify the most effective ways of utilising HUSAR Poland's medical component in international operations, immediately after the search \& rescue phase involving the recovery of victims from the rubble (known as beyond the rubble) is completed, so that its potential can be used in full to meet the expectations of the affected communities and the local emergency services. These conclusions suggest that a possible role could be to serve the functions similar to those defined by the World Health Organisation for Foreign Medical Teams Type 1. Keywords: INSARAG, HUSAR POLAND, rescue, medical team, Nepal, earthquake Type of article: case study

Received: 14.05.2018; Reviewed: 27.06.2018; Accepted: 05.11.2018;

The authors contributed equally to this article;

Authors' ORCID IDs: M. Chomoncik - 0000-0002-2535-488X; M. Feltynowski - 0000-0001-5614-8387; L. Smolarczyk - 0000-0002-9028-0485;

Please cite as: BiTP Vol. 51 Issue 3, 2018, pp. 104-118, doi: 10.12845/bitp.51.3.2018.7;

This is an open access article under the CC BY-SA 4.0 license (https://creativecommons.org/licenses/by-sa/4.0/).

\section{АННОТАЦИЯ}

Цель: Авторы статьи, участники акции тяжелой поисково-спасательной группы Государственной пожарной службы (HUSAR Польша) после землетрясения в Непале в 2015 году, на основе представленного тематического исследования, попытались ознакомить читателей со спецификой работы медицинского подразделения этой специализированной группы.

Введение: Во введении перечислены основные организационные подразделения ГПС, членами которых являются участники Группы спасателей, уточнены обстоятельства ее официального создания, в том числе назначение первой поисково-спасательной команды под руководством Главного командующего ГПС. Затем была описана роль стандартизованных принципов поисково-спасательных операций Национальной спасательной и пожарной системы, и были представлены результаты работы международных спасательных операций по ликвидации последствий землетрясений, в которых участвовали польские пожарные. Затем, прояснив правовое предписание Международной консультативной поисково-спасательной группы (INSARAG) и роль ее руководящих принципов в определении минимальных международных стандартов, авторы разъяснили состав всех компонентов HUSAR Польша. Целью исследования являлось получение ответа на вопрос об оптимальном способе использования потенциала медицинского подразделения HUSAR Польша во время зарубежных поисково-спасательных операций.

Методы: В качестве исследовательских материалов были использованы международные и национальные нормативные документы, регулирующие функционирование HUSAR Польша, и определяющие минимальные стандарты для поисково-спасательных групп и иностранных медицинских бригад. Анализ участия HUSAR Польша в Непале в 2015 году и выводы из кампании на Гаити в 2010 году. Основным методом исследования был анализ документов и статистики. В тексте представлены задачи медицинского подразделения USAR Польша на разных этапах так называемого «Цикла миссии» и документы, используемые на практике. Особое внимание, в соответствии с названием статьи, посвящено представлению реализации медицинских задач, выполненных во время акции в Непале. Авторы не только представили примеры статистических данных о деятельности медицинского подразделения Группы в Непале, но также сравнили ее с участием в подобной акции, проведенной на Гаити в 2010 году.

Резюме: В резюме и выводах авторы предприняли попытки указать наиболее эффективное использование медицинского подразделения HUSAR Польша в международной акциях сразу после поисково-спасательной операции, связанной с освобождением потерпевших из-под завалов (так называемая концепция действий после освобождения из-под завалов), с тем чтобы ее возможности использовались оптимально, полностью соответствуя ожиданиям пострадавшего сообщества и тех, учреждений, которые управляют стихийным бедствием. Были сформулированы выводы, согласно которым предлагалось выполнение задач, совпадающих с теми, которые предусмотрены Всемирной организацией здравоохранения для иностранной медицинской бригады 1-го типа».

Ключевые слова: INSARAG, HUSAR POLAND, служба спасения, спасательная группа, Непал, землетрясение

Вид статьи: исследование случая

Принята: 14.05.2018; Рецензирована: 27.06.2018; Одобрена: 05.11.2018;

Авторы внесли одинаковый вклад в создание этой статьи;

Идентификаторы ORCID авторов: M. Chomoncik - 0000-0002-2535-488X; M. Feltynowski - 0000-0001-5614-8387; L. Smolarczyk - 0000-0002-9028-0485; Просим ссылаться на статью следующим образом: BiTP Vol. 51 Issue 3, 2018, pp. 104-118, doi: 10.12845/bitp.51.3.2018.7;

Настоящая статья находится в открытом доступе и распространяется в соответствии с лицензией CC BY-SA 4.0 (https://creativecommons.org/ licenses/by-sa/4.0/). 


\section{Wstęp}

Początkowo Ciężką Grupę Poszukiwawczo-Ratowniczą Państwowej Straży Pożarnej (ang. Heavy Urban Search and Rescue - USAR Poland) tworzyli przede wszystkim ratownicy z pięciu grup poszukiwawczo-ratowniczych w Polsce (Małopolska, Gdańsk, Warszawa, Łódź, Poznań) oraz dowództwo z Komendy Głównej PSP. Pomimo że specjalistyczne grupy poszukiwawczo-ratownicze funkcjonowały przez kilkanaście lat oraz brały udział w akcjach i ćwiczeniach międzynarodowych, HUSAR Poland, jako formalna struktura została powołana dopiero $w$ listopadzie 2009 roku. Było to możliwie dzięki pozytywnemu wynikowi egzaminu certyfikującego do działań ratowniczych przeprowadzonego przez Międzynarodową Grupę Doradczą ds. Poszukiwania i Ratownictwa (The International Search and Rescue Advisory Group - INSARAG) działającą w ramach Organizacji Narodów Zjednoczonych. Egzamin ten odbył się w dniach 6-10 kwietnia $2009 \mathrm{r}$. [2]. Przygotowanie do niego było realizowane na podstawie decyzji Nr 133 Komendanta Głównego Państwowej Straży Pożarnej z dnia 5 września 2008 r. o powołaniu zespołu do przygotowania ciężkiej GPR PSP do certyfikacji INSARAG, a następnie Rozkazu nr 8 KG PSP z 2014 r. dot. realizacji ćwiczenia certyfikującego.

Postanowiono wtedy o zwróceniu większej uwagi na rozwijającą się w PSP mało dookreśloną specjalizację poszukiwawczo-ratowniczą. W tym celu decyzją nr 22 z dnia 25 maja 2009 r. Komendant Główny PSP powołał - analogicznie jak w przypadku ratownictwa wodnego, chemiczno-ekologicznego i wysokościowego - zespół do spraw ratownictwa poszukiwawczo-ratowniczego [3, s. 114]. Jednym z pierwszych celów powołanego Zespołu zostało wypracowanie propozycji prawnego, centralnego sformalizowania i uporządkowaniu struktury specjalizacji poszukiwawczo-ratowniczej, przewidzianej do działań (akcji i ćwiczeń) poza granicami państwa oraz rozpoczęcie pracy nad dokumentem opisującym tę specjalizację na wszystkich poziomach, od podstawowego do międzynarodowego [3, s. 115]. Na wiosnę 2018 r. w skład HUSAR Poland wchodzili już przedstawiciele aż 11 jednostek organizacyjnych PSP [1].

Strażacy-ratownicy z Polski wzięli udział w działaniach ratowniczych po trzęsieniach ziemi w następujących państwach:

- Armenii (grudzień 1988),

- Turcji (sierpień, listopad 1999),

- Indiach (styczeń 2001),

- Algierii (maj 2003),

- Iranie (grudzień 2003),

- Pakistanie (październik 2005),

- Indonezji (maj 2007),

- Haiti (styczeń 2010),

- Nepalu (kwiecień 2015).

\section{INSARAG}

INSARAG to sieć ponad 80 krajów i organizacji skupionych pod patronatem Organizacji Narodów Zjednoczonych (ONZ). Początki INSARAG sięgają roku 1988, w którym doszło do trzęsienia ziemi w Armenii. Napotkane podczas prowadzenia

\section{Introduction}

Initially, the Heavy Urban Search and Rescue (HUSAR) Poland, included mainly rescuers from five search and rescue groups in Poland (Małopolska, Gdańsk, Warsaw, Łódź, Poznań) and command from the State Fire Service Headquarters. While specialist search and rescue groups have functioned for over a dozen years and have taken part in international operations and exercises, HUSAR Poland, as a formal structure, was not set up until November 2009. This was possible with positive results of the rescue operations certification exam carried out by the International Search and Rescue Advisory Group (INSARAG), which operates within the United Nations structures. The exam took place on 6-10 April 2009. [2]. Preparations for the exam were based on Decision No. 133 of the Chief Commander of the State Fire Service (SFS) of 5 September 2008 on setting up a team for preparing the State Fire Service's heavy USAR for INSARAG certification, and later Order No. 8 of the Chief Commander of the SFS of 2014 on the certification exercise.

This is when a decision was made to pay more attention to a vaguely defined search \& rescue specialisation, which was only being developed at the SFS at the time. For this purpose, similarly to water, chemical and environmental, and high-altitude rescue services, the Chief Commander of the SFS issued Decision No. 22 of 25 May 2009 to set up a search and rescue team [3, p. 114]. One of the first objectives for the Team was to develop its proposed legal, centralised formal framework and to organise the structure of the search and rescue specialisation, designed for service (operations and exercises) outside the country, and to commence work on a special document to describe this specialisation at all levels, from basic to international [3, p. 115]. In spring 2018, HUSAR Poland already included representatives of as many as 11 units of the SFS [1].

Firefighters-rescuers from Poland took part in rescue operations following earthquakes in the following countries:

- Armenia (December 1988),

- Turkey (August and November 1999),

- India (January 2001),

- Algeria (May 2003),

- Iran (December 2003),

- Pakistan (October 2005),

- Indonesia (May 2007),

- Haiti (January 2010), and

- Nepal (April 2015).

\section{INSARAG}

INSARAG is a network of more than 80 countries and organisations under the United Nations (UN) umbrella. The network was established in 1988, when an earthquake struck Armenia. The problems faced during those operations, including the lack 
działań problemy (między innymi brak procedur dotyczących koordynacji działania, różnice w wyposażeniu i możliwościach poszczególnych grup) potwierdziły konieczność unormowania tego rodzaju pomocy. Oficjalnie INSARAG powstała w $1991 \mathrm{r}$. W roku założycielskim organizacji zespół międzynarodowych ekspertów opracował swoistą podstawę organizowania, funkcjonowania i działania grup USAR w sytuacji wystąpienia trzęsienia ziemi (wytyczne INSARAG). W Wytycznych uwzględnione zostały także zadania określone w Rezolucji Zgromadzenia Ogólnego nr 57/150 z dnia 16 grudnia 2002 r. o wzmocnieniu efektywności i koordynacji międzynarodowej pomocy w dziedzinie poszukiwania i ratownictwa na terenach zurbanizowanych [4]. Mając na celu usprawnienie mechanizmów pomocy, Wytyczne wprowadzają minimalne standardy działania wszystkich międzynarodowych grup poszukiwawczo-ratowniczych oraz sposobu koordynacji międzynarodowej pomocy po trzęsieniu ziemi. Zawierają one zasady udzielania pomocy ratowniczej przez USAR od chwili alarmowania grupy, przez fazę mobilizacji, transportu do kraju potrzebującego pomocy i działania ratownicze na jego terenie do czasu ich zakończenia i powrotu do kraju. Dokumentem opisującym organizację Polskich Specjalistycznych Grup Poszukiwawczo-Ratowniczych są Zasady organizacji działań poszukiwawczo-ratowniczego w krajowym systemie ratowniczo-gaśniczym opracowane w KG PSP [5].

W skład Grupy USAR wchodzi:

- zespół dowódczy,

- zespół logistyczny,

- zespół operacyjny.

Zespół operacyjny składa się z:

- komponentu rekonesansu,

- komponentu operatorów urządzeń lokalizacyjnych,

- komponentu ratowników,

- komponentu ratowników medycznych / lekarzy (komponent medyczny),

- oficera ds. spraw bezpieczeństwa budowli i materiałów niebezpiecznych (ang. HAZMAT),

- komponentu przewodników psów z psami.

Fazy działań międzynarodowych USAR:

- faza gotowości,

- faza mobilizacji,

- faza działania,

- faza demobilizacji,

- faza po misji.

\section{Komponent medyczny USAR}

W wytycznych INSARAG znajdują się szczegółowe zadania USAR dla poszczególnych komponentów. W przypadku komponentu medycznego zadania te przedstawiają się $\mathrm{w}$ następujący sposób.

I. W fazie "gotowości" komponent medyczny jest odpowiedzialny za utrzymanie gotowości operacyjnej i ogólnych wymagań określonych przez taktykę USAR. W związku z tym członkowie komponentu powinni dbać o:

- odpowiednie szczepienia dla członków grupy, of procedures concerning action coordination and differences in equipment and capabilities of different groups, confirmed the need to develop uniform standards for such rescue services. Officially, INSARAG was established in 1991. In its founding year, a team of international experts developed specific guidelines to serve as the basis for the organisation, functioning and operation of USAR groups in case of an earthquake (INSARAG Guidelines). The Guidelines also included the tasks specified in General Assembly Resolution No. 57/150 of 16 December 2002 - Strengthening the effectiveness and coordination of international urban search and rescue assistance [4]. Designed to make assistance provision more efficient, the Guidelines introduce minimum operating standards for all international search and rescue groups, and methods of coordinating international support following earthquakes. They include the rules for rescue assistance by USAR from the time the group is alarmed, to its mobilisation, transport to the affected country, rescue operations on its territory until their completion, and return to the home country. The document that describes the organisation of Polish specialist search and rescue groups is entitled "Rules for the organisation of search and rescue operations within the national rescue and fire-fighting system", as developed by the SFS Headquarters [5].

Each USAR Group includes:

- management team,

- logistics team,

- operations team.

The operations team comprises:

- search component,

- locating system operators component,

- rescue component,

- medical rescuer / doctor component (medical component),

- building safety and hazardous materials (HAZMAT) officer,

- search \& rescue dogs and handlers component.

Phases of international USAR operations:

- preparedness phase,

- mobilisation phase,

- operations phase,

- demobilisation phase,

- post-mission phase.

\section{Medical component of USAR}

INSARAG Guidelines describe specific USAR roles and responsibilities for each component. Response objectives for the medical component are as follows.

I. During the Preparedness phase, the medical component is required to maintain a constant state of mission readiness and comply with all other general requirements as determined by USAR team policy. Consequently, component members should

- have appropriate vaccinations for working in the affected country recommended by national health authorities, 
- odpowiedni zapas środków medycznych,

- oraz określić sposób monitorowania stanu zdrowia ratowników podczas działań poza granicami kraju.

II. W fazie "mobilizacji” do zadań członków komponentu medycznego należą:

- zapoznanie się z zagrożeniami zdrowotnymi i medycznymi, jakie występują w kraju działań,

- dokonanie oceny lokalnego systemu pomocy medycznej w celu podjęcia próby odpowiedzi na pytanie, czy system lokalny jest w stanie pokryć potrzeby wynikające ze zdarzenia,

- przeprowadzenie przed wylotem wstępnego badania medycznego ratowników i psów ratowniczych oraz kontrolę wymaganej, międzynarodowej dokumentacji medycznej,

- koordynacja planu działań z osobami funkcyjnymi odpowiedzialnymi za bezpieczeństwo,

- przygotowanie planu zabezpieczenia medycznego na czas transportu.

Dostęp do leków dla USAR Poland realizowany był zgodnie z Decyzją Małopolskiego Wojewódzkiego Inspektora Farmaceutycznego w Krakowie z dnia 19.12.2013 r., w której wyraził on zgodę na posiadanie przez SA PSP w Krakowie w celach medycznych preparatów zawierających w swoim składzie środki odurzające lub psychotropowe (FAKR - I.857.1.214.2013).

III. W fazie "działań" komponent medyczny jest odpowiedzialny za:

- rozpoznanie dostępności lokalnych i międzynarodowych zasobów medycznych,

- uzyskanie informacji w zakresie lokalnych procedur medycznych w zakresie zgłaszania rannych, przekazywania rannych, zarządzania informacjami o poszkodowanych, sposobie utylizacji odpadów medycznych oraz określenie zasad komunikacji z lokalnymi zasobami ratownictwa medycznego,

- dostarczenie danych medycznych niezbędnych w procesie podejmowania decyzji,

- promowanie z oficerem bezpieczeństwa i dowódcą komponentu logistycznego zachowania, które będzie gwarantowało bezpieczeństwo zdrowotne i higienę ratowników w obozie i strefie roboczej,

- stałe monitorowanie stanu zdrowia członków grupy, a w razie potrzeby doraźną opiekę dla ratowników oraz psów ratowniczych,

- współpracę z komponentem ratowniczym, która ma na celu zapewnienie prawidłowej pomocy medycznej uwięzionym poszkodowanym oraz bezpieczną ich ewakuację.

IV. Podczas demobilizacji komponent medyczny:

- koordynuje demobilizację z lokalnymi organami pomocy medycznej,

- przekazuje informacje i dokumenty wskazanym organizacjom medycznym,

- sporządza listę sprzętu i środków medycznych do przekazania,

- przewiduje możliwe zagrożenia dla zdrowia ratowników związane z działaniami oraz określa potencjalne wymagania na późniejszą interwencję medyczną,
- maintain the medical cache stored in clearly labelled containers with attached inventory list for deployment and border-crossing, and

prepare processes to efficiently medically screen all personnel at the time of international deployment.

II. During the Mobilisation phase, USAR Team Medical Component is required to:

- conduct remote information gathering to include the receiving country specific health and medical risks.

- assess the local medical system to determine if it can effectively cope with the impact of the situation or if the system is extended beyond its capabilities,

- prior to deployment, conduct the medical screening process for USAR team personnel and search dogs as well as a review of the required international documentation,

- coordinate with Safety and hazmat functions to clarify overlapping concerns, and

- determine medical plan for in-transit phase and be prepared to adjust en route.

Access to medications for USAR Poland was based on the Decision of the Provincial Pharmaceutical Inspector in Kraków of 19 December 2013, which authorised College of the State Fire Service in Kraków to hold, for medical purposes, preparations including narcotic or psychotropic substances (FAKR - I.857.1.214.2013).

III. During the Operations phase, the medical component is expected to:

- identify the availability of local and international medical resources,

- obtain information about local medical procedures such as: casualty handover, casualty transport, fatality management, and medical waste disposal, and to specify methods of regular communications with local health authorities,

- provide medical input into USAR team decision making/ planning process,

- coordinate with Safety, hazmat, and Logistics functions to promote safe health and hygiene practices (BoO and work sites),

- provide continuous health monitoring and medical care to USAR team members (to include canines), and

- integrate with Rescue function to provide emergency medical care to entrapped victims and to ensure safe patient extrication.

IV. During Demobilisation, USAR Team Medical Component:

- coordinates demobilisation with local relevant health authorities,

- provides handover to relevant medical organisations,

- identifies appropriate medical cache donations,

- assesses potential exposures and need for follow on medical care, and

- maintains in-transit medical care for team to home base.

V. After return to home base, the medical component is required to: 
- zapewnia opiekę medyczną dla członków grupy na czas powrotu.

V. Po powrocie do kraju do zadań komponentu medycznego należy:

- w razie konieczności razem z pionem dowódczym koordynacja natychmiastowej i długoterminowej pomocy medycznej dla ratowników (w tym również pomocy psychologicznej),

- odtworzenie wyrobów i środków medycznych,

- dostarczenie danych i wniosków do końcowego raportu.

Członkowie komponentu medycznego w ramach funkcjonowania ciężkiej grupy zobowiązani są do posiadania wyrobów i środków medycznych oraz wiedzy, jak je stosować. Umiejętności w tym zakresie pozwalają na podjęcie następujących działań:

- resuscytacji krążeniowo-oddechowej,

- zaawansowanych technik udrażniania dróg oddechowych,

- podawania tlenu przez maskę, cewnik i wentylacji workiem samorozprężalnym,

- kontroli krwawienia,

- zaopatrywania ran,

- leczenia wstrząsu,

- sedacji i leczenia przeciwbólowego,

- postępowania w przypadku odmy,

- stabilizacji i unieruchamiania kończyn,

- oparzenia i innych zagrożeń środowiskowych,

- postępowania w zespole zmiażdżenia,

- postępowania w sytuacji amputacji urazowej i koniecznośc rozczłonkowania,

- segregacji medycznej,

- zabezpieczenia przy narażeniu na czynniki zakaźne,

- przemieszczania poszkodowanych,

- ochrony zdrowia psychicznego, w tym rozpoznawania nieprawidłowych reakcji na stres wśród członków zespołu i zapobieganie im,

- udzielania pierwszej pomocy oraz wstępnej opieki weterynaryjnej dla psów ratowniczych we współpracy z przewodnikami.

Ponadto członkowie komponentu medycznego muszą mieć opracowaną procedurę postępowania w sytuacji, gdy ratownik zostanie poważnie ranny lub kiedy będzie umierać. Podobna procedura w uzgodnieniu z lokalnymi władzami (ang. LEMA - Local Emergency Management Authority - Lokalne Struktury Zarządzania w Sytuacjach Kryzysowych) musi być opracowana na wypadek śmierci lub kontaktu ze zmarłymi osobami z lokalnej populacji.

\section{Trzęsienie ziemi w Nepalu w roku 2015 - działania komponentu medycznego HUSAR Poland}

W dniu 25 kwietnia 2015 r. miało miejsce trzęsienie ziemi o sile 7,8 stopnia w skali Richtera z epicentrum w Nepalu. Odnotowano po nim kolejnych 18 wstrząsów wtórnych o sile powyżej 4 stopnia w skali Richtera. W wyniku trzęsienia ziemi śmierć poniosło 8964 osób, a rannych zostało co najmniej 23500 osób. Drugie trzęsienie ziemi wydarzyło się 12 maja i spowodowało około 2500 dodatkowych obrażeń i 200 zgonów [6].
- coordinate immediate and long term medical follow-up with USAR Team Management (including mental health),

- rehabilitate USAR medical cache,

- provide input into USAR team post mission operations report.

Members of HUSAR Medical Team are required to have the medical products and devices, and to know how to use these. These skills support the following actions:

- CPR,

- advanced airway management,

- oxygen administration through a mask, cannula and bag ventillation,

- haemorrhage control,

- wound care,

- treatment for shock,

- sedation and pain management,

- management of tension pneumothorax

- immobilisation and packaging,

- burns and environmental emergencies,

- management of crush syndrome,

- amputations and dismemberment,

- medical triage,

- procedures for hazardous materials exposure,

- casualty evacuation,

- mental health protection, including the identification and prevention of inappropriate stress responses among team members,

- first aid and emergency veterinary care for the USAR team search dogs in collaboration with their handlers.

Moreover, medical teams are required to have a procedure for dealing with serious injury or fatality amongst team members. A similar procedure needs to be agreed with the Local Emergency Management Authority (LEMA) for deceased team members or finding deceased members of the local population.

\section{5 earthquake in Nepal - HUSAR Poland Team Medical operations}

On 25 April 2015, an earthquake with a magnitude of 7.8 on the Richter scale, hit Nepal. It was followed by 18 aftershocks with a magnitude above 4 on the Richter scale. As a result of the earthquake, 8964 people perished, and 23,500 became injured. A second earthquake took place on 12 May and killed another 200 people, while some 2,500 more were injured [6]. Based on Order No. 13, issued by the CO SFS on 25 April 2015, 
Na podstawie Rozkazu Komendanta Głównego PSP nr 13 z dnia 25 kwietnia 2015 r. w akcji Nepal 2015 udział wziął HUSAR Poland. Grupa została przetransportowana na miejsce akcji samolotem PLL LOT Boeing 767 "Dreamliner".

Przez pierwsze dni grupa realizowała zadania poszukiwawczo-ratownicze oraz rozpoznawcze. Wspierała także proces ewakuacji polskich obywateli do kraju. Zgodnie z wytycznymi INSARAG istnieje pięć poziomów rozpoznania - ostatni piąty świadczy o tym, że wszystkie ciała zostały wydobyte. W piątym dniu pobytu grupy w Nepalu (30.04) kończyła się faza ratownicza i rozpoczynała humanitarna (zapewnianie dostępu do zwłok i ich wydobycie, stabilizacja konstrukcji, rozpoznanie procedury przyjęcia i dystrybucji wewnętrznej pomocy humanitarnej).

Na porannej odprawie dowódców grup międzynarodowych w lokalnym sztabie zarządzania w sytuacji kryzysowej (LEMA), który w przypadku Nepalu tworzyły struktury wojskowe (ang. Multi National Military Coordination Center - MNMCC), przedstawiciel Światowej Organizacji Zdrowia (ang. World Health Organization, WHO) odpowiedzialny za koordynację działań międzynarodowych grup medycznych (Foreign Medical Teams - FMT) poprosił Grupę o rozpoznanie potrzeb medycznych w kilku wskazanych dystryktach [7]. Dowództwo Grupy, zgodnie z polityką INSARAG dotyczącą działań „beyound the rubbles - poza gruzami", przychyliło się do prośby i podjęło decyzję o wysłaniu komponentu medycznego na północny-wschód od Katmandu, w północno-wschodniej części regionu Sindupalchowk, tuż przy granicy z Tybetem. To w tych rejonach najwięcej miejscowości było odciętych od świata, a pomoc do poszkodowanych kierowana była przy użyciu śmigłowców wojskowych. Grupa 16 ratowników (w tym 2 lekarzy i 7 ratowników medycznych) w godzinach popołudniowych dotarła do miejscowości Barhabise. Jest ona położona 27 kilometrów od granicy z Chinami oraz stanowi ostatni punkt, do którego można było dojechać samochodem. W odległości około 5 kilometrów od miasta w kierunku granicy z Chinami doszło do osunięcia ziemi i kamieni na drogę, co skutecznie uniemożliwiło ruch kołowy. Po wstępnym rozpoznaniu i nawiązaniu kontaktu z lokalnymi placówkami służby zdrowia (były częściowo zniszczone) członkowie zespołu zorganizowali doraźny punkt pomocy medycznej, na który składały się dwa namioty.
HUSAR Poland joined Operation Nepal 2015. The group was deployed to the affected teritory by Boeing 767 "Dreamliner" operated by PLL LOT.

Initially, the group implemented search \& rescue and reconnaissance tasks. It also supported the process of evacuating Polish citizens back home. As per INSARAG Guidelines, there are five levels of reconnaissance - the final, fifth, level means that all bodies have been recovered. On the fifth day on site (30 April), the rescue phase was completed and the humanitarian phase commenced (providing access to and recovering bodies, building structure stabilisation, identification of the procedures for the acceptance and distribution of domestic humanitarian aid).

During the morning debriefing for leaders of international groups, at the local LEMA headquarters, which in Nepal was represented by its military structures, Multi National Military Coordination Centre, a representative of the World Health Organisation (WHO), responsible for coordinating Foreign Medical Teams (FMT) asked the Group to assess the medical needs in a few specific districts [7]. In line with the INSARAG policy related to beyond the rubble relief operations, the Group Management agreed to oblige and decided to send its medical team north east of Kathmandu, to the north-eastern part of Sindhupalchok District, next to the border with Tibet. This region had the largest number of areas cut off from the rest of the world, and victims received assistance using military helicopters. A group of 16 rescuers (including 2 doctors and 7 medical rescuers) arrived in Bahrabise in the afternoon. The city is located 27 kilometres from the border with China and constitutes the most remote place reachable by car. Within some 5 kilometres from the city towards the border with China there had been a landslide and rockfall, which effectively blocked any vehicular traffic. After initial assessment and contacting local health care facilities (which were partially damaged), team members organised an ad-hoc medical assistance point with two tents.

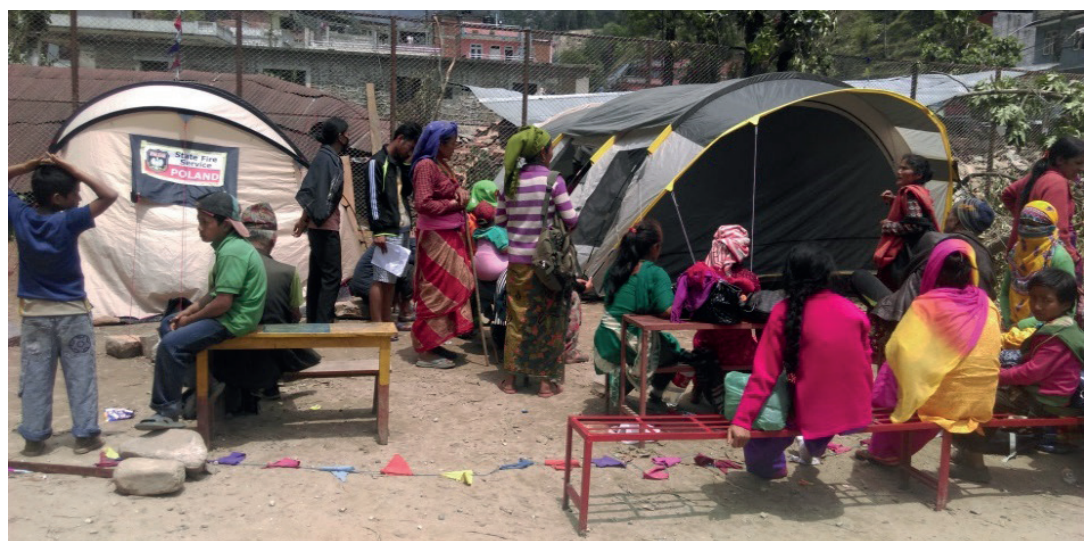

Rycina 1. Doraźny punkt pomocy medycznej

Figure 1. Emergency medical help point

Źródło: Archiwum HUSAR Poland.

Source: HUSAR Poland Archives. 
Od godzin popołudniowych do następnego dnia do ok. godz. 14 do punktu zgłosiło się w sumie 50 osób w różnym wieku. W godzinach nocnych punkt medyczny był w gotowości do zdarzeń nagłych (dyżur 2 ratowników), lecz nie przyjmował pacjentów.
From the afternoon that day until about 2 p.m. the next day about 50 people of various ages reported to the point. At night, the point was ready to respond to emergencies (2 rescuers on duty) but did not receive any patients.

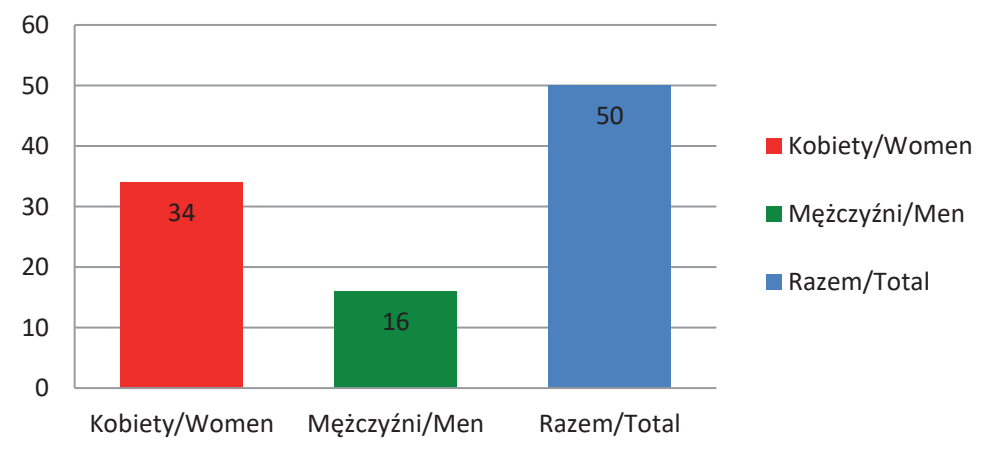

Rycina 2. Osoby zgłaszające się do punktu medycznego z podziałem na płeć

Figure 2. People reporting to the medical point, broken down by gender

Źródło: Opracowanie własne.

Source: Own elaboration.

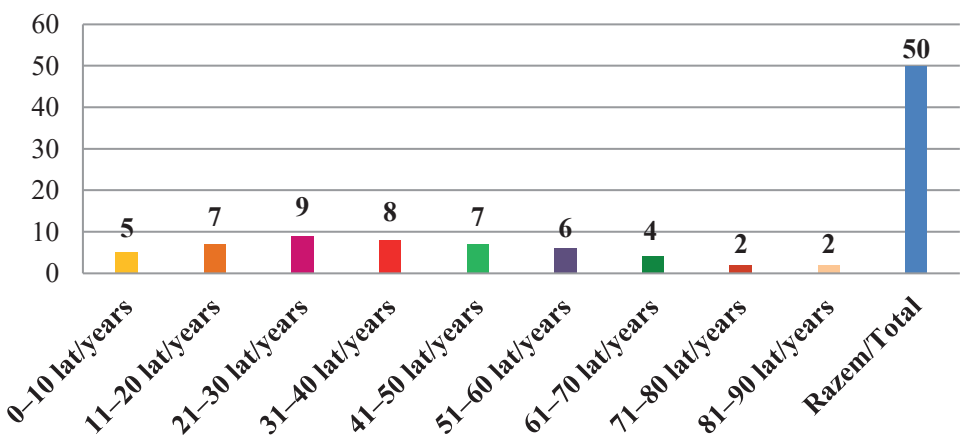

Figure 3. People reporting to the medical point, broken down by age

Rycina 3. Osoby zgłaszające się do punktu medycznego z podziałem na wiek

Źródło: Opracowanie własne.

Source: Own elaboration.

Głównymi powodami zgłoszenia się do punktu medycznego były obrażenia doznane podczas trzęsienia ziemi.
The main reasons for reporting to the medical point were injuries suffered during the earthquake.

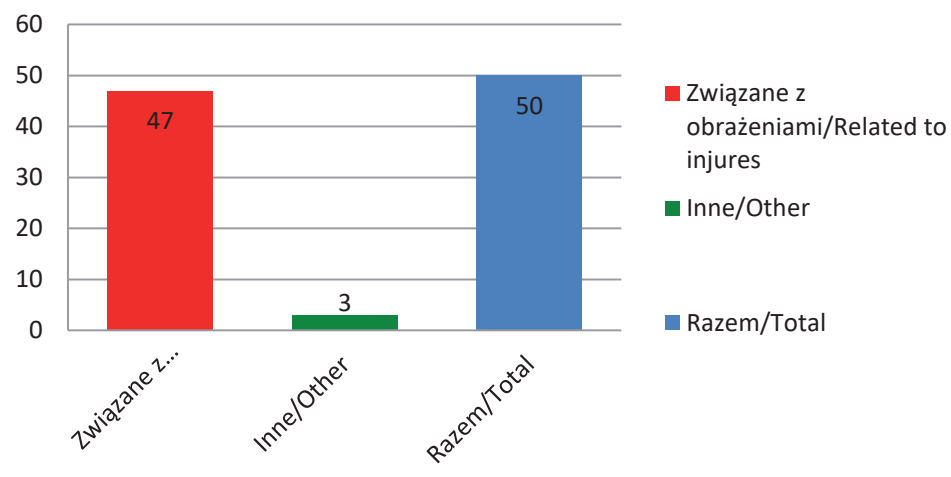

Rycina 4. Powody zgłoszenia się do punktu medycznego

Figure 4. Reasons to report to a medical point

Źródło: Opracowanie własne.

Source: Own elaboration. 
Głównymi obrażeniami, z którymi mieli do czynienia ratownicy, były powierzchowne rany głowy, stłuczenia klatki piersiowej, stłuczenia i złamania kończyn, zranienia powierzchowne z przerwaniem ciągłości tkanek. Ze względu na to, że rany nie były opatrzone bezpośrednio po doznanym obrażeniu (rany zastarzałe) konieczne było ich oczyszczenie, dezynfekcja i założenie jałowych opatrunków. Obrażenia wymagały regularnej kontroli najpierw w punkcie medycznym (przez 1 dzień), a następnie w placówce utworzonej przez Japończyków lub w lokalnych placówkach służby zdrowia. U kilku poszkodowanych po badaniu przedmiotowym zaistniało podejrzenie złamania kości udowej. Tych pacjentów po unieruchomieniu, nawodnieniu i zabezpieczeniu przeciwbólowym przekazano do lokalnych placówek służby zdrowia ( $w 1$ dniu pobytu) oraz do japońskiego szpitala polowego (w 2 dniu). Głównych 47 przyczyn zgłoszenia się do punktu medycznego, związanych z obrażeniami, przedstawionych zostało poniżej (ryc. 5a i 5b).
The most common injuries treated by rescuers were superficial head injuries, bruised chest, bruised or broken extremities, and superficial cuts. Since these wounds were not managed immediately after the incident (old wounds), they had to be cleaned, disinfected, and dressed. The injuries required regular monitoring, first at the medical point (for 1 day), and then at a facility established by the Japanese, or at local health care centres. After physical examination, a few victims were diagnosed with possible thigh bone fracture. After immobilisation and pain management, those patients were transferred to local health care centres (day 1) and to the Japanese field hospital (day 2). 47 most common reasons for reporting to the medical point, related to various injuries, are presented below (Figs. 5a and 5b).

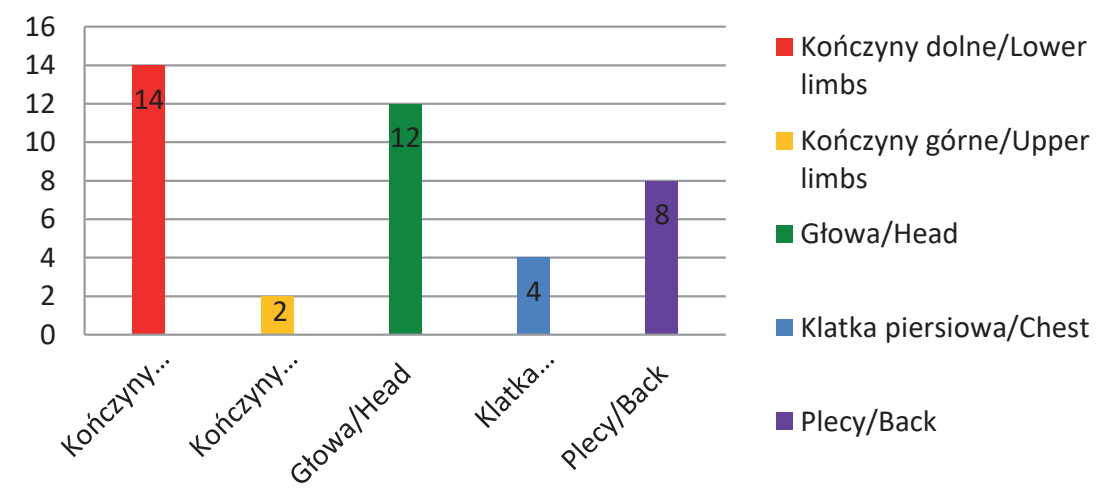

Rycina 5a. Powody zgłoszenia się do punktu medycznego związane z obrażeniami - cz. I

Figure 5a. Reasons for reporting to the medical point related to injuries - part I

Źródło: Opracowanie własne.

Source: Own elaboration.

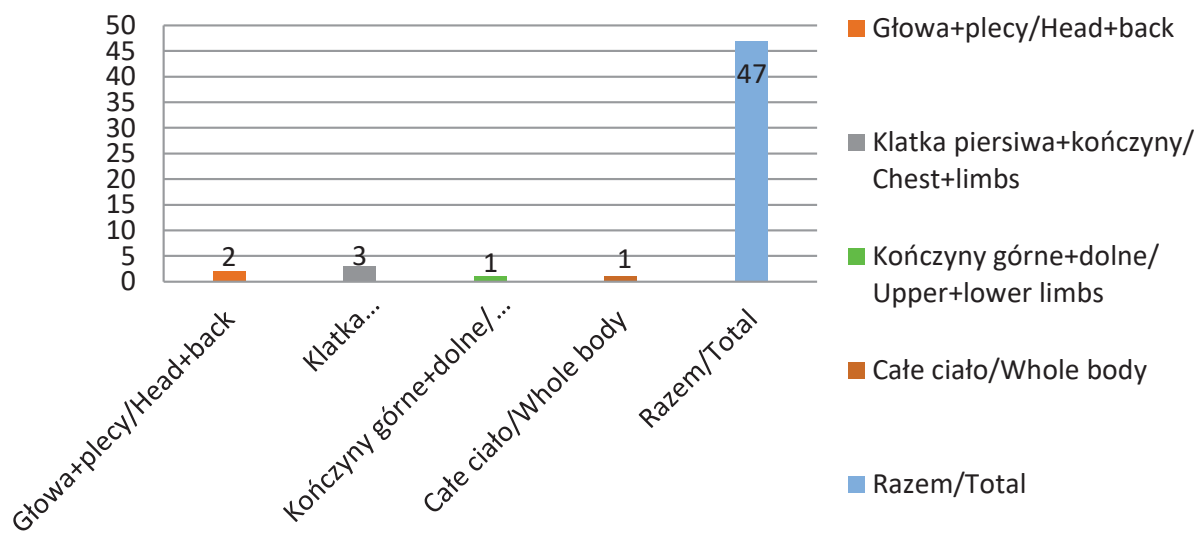

Rycina 5b. Powody zgłoszenia się do punktu medycznego związane z obrażeniami - cz. Il i łącznie

Figure 5b. Reasons for reporting to the medical point related to injuries- part II and summary

Źródło: Opracowanie własne.

Source: Own elaboration 


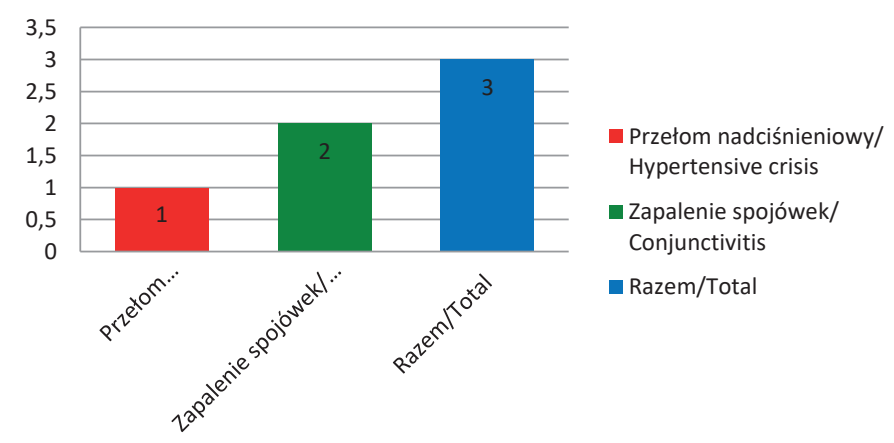

Rycina 6. Inne powody zgłoszenia się do punktu medycznego

Figure 6. Other reasons for reporting to the medical point

Żródło: Opracowanie własne.

Source: Own elaboration.

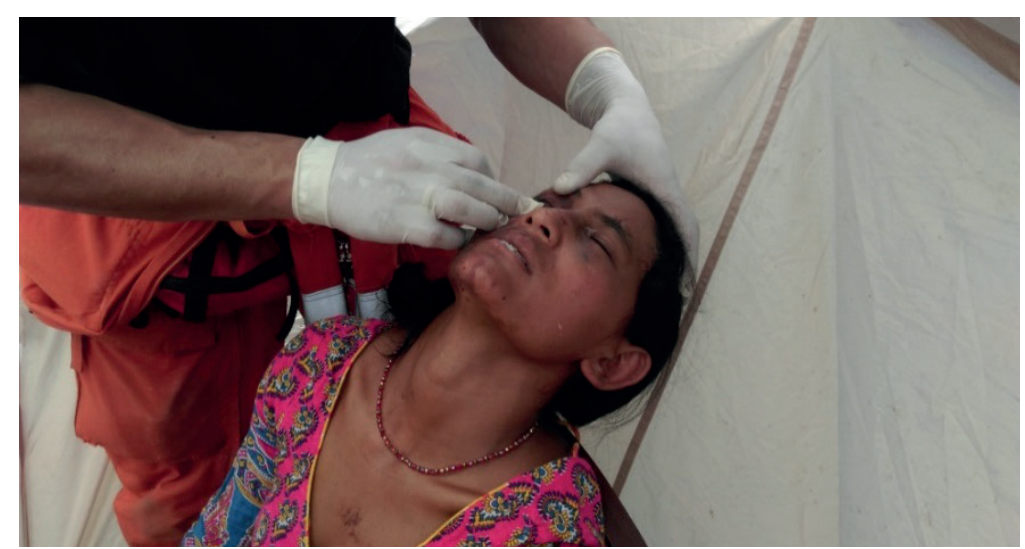

Figure 7a. Examples of injuries

Rycina 7a. Przykładowe obrażenia

Source: HUSAR Poland Archives.

Źródło: Archiwum HUSAR Poland.

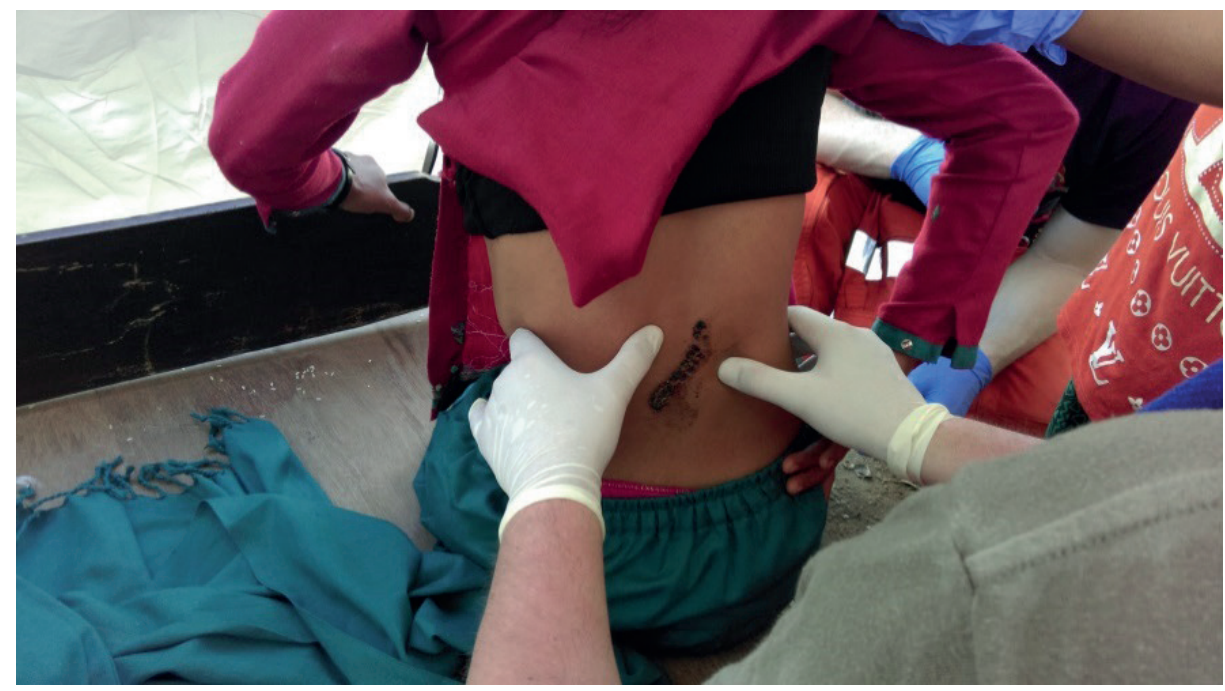

Rycina 7b. Przykładowe obrażenia

Figure $7 \mathrm{~b}$. Examples of injuries

Źródło: Archiwum HUSAR Poland.

Source: HUSAR Poland Archives. 


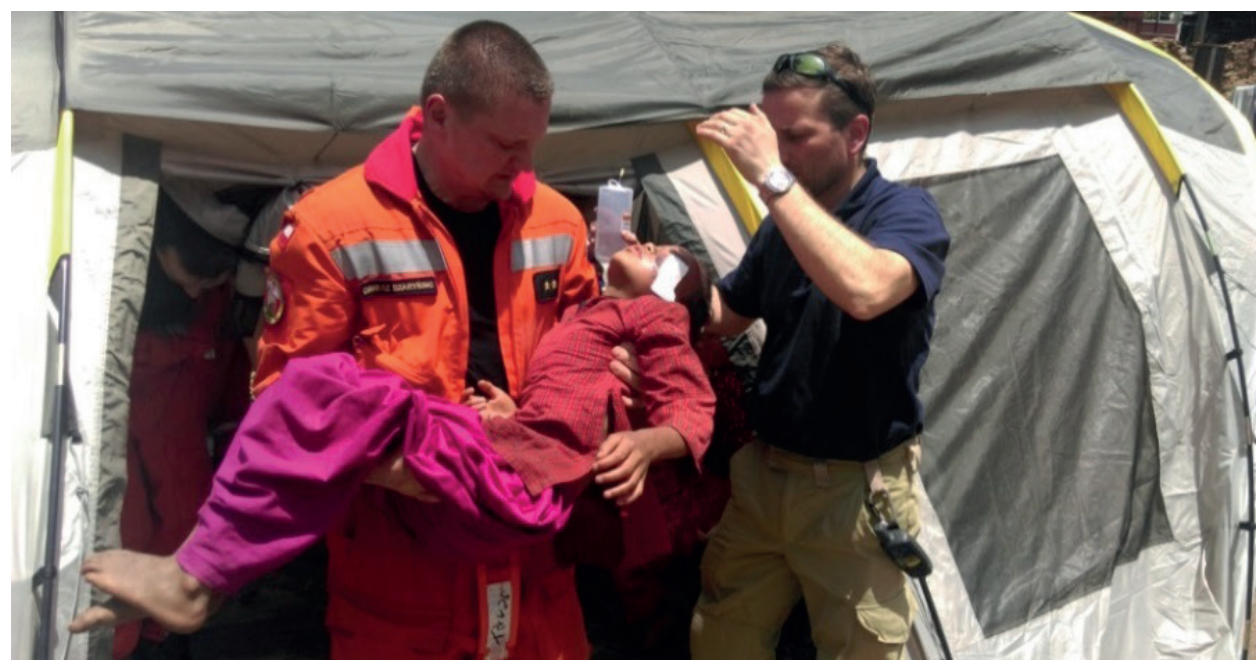

Rycina 7c. Przykładowe obrażenia

Figure 7c. Examples of injuries

Źródło: Archiwum HUSAR Poland.

Source: HUSAR Poland Archives.

Z wykazu leków zabieranych na akcje zagraniczne, w Nepalu ratownicy z komponentu medycznego wykorzystali te przedstawione w tabeli poniżej [8].
Out of the list of medications for international operations, in Nepal the medical team used those listed in the table below [8].

Tabela 1. Leki zużyte podczas udzielania pomocy [8]

Table 1. Drugs used while providing assistance [8]

\begin{tabular}{|c|c|c|}
\hline Name/Nazwa & International name/Nazwa międzynarodowa & $\begin{array}{l}\text { Quantity/ } \\
\text { Liczba }\end{array}$ \\
\hline Aldesan E, 2\%, płyn 1 I/Aldesan E, 2\%, liquid 1 I & Glutaraldehyde, ethyl alcohole, aqua & 2 \\
\hline Altacet $1 \mathrm{~g}$, tabl., 6 szt./Altacet $1 \mathrm{~g}$, tabl., 6 pcs & Aluminii acetotartras & 4 \\
\hline Altacet $1 \%(10 \mathrm{mg} / \mathrm{g})$, żel $75 \mathrm{~g}$, tuba/Altacet $1 \%(10 \mathrm{mg} / \mathrm{g})$, gel $75 \mathrm{~g}$, tube & Aluminii acetotartras & 2 \\
\hline Argosulfan $2 \%(20 \mathrm{mg} / \mathrm{g})$, krem $40 \mathrm{~g} /$ Argosulfan $2 \%(20 \mathrm{mg} / \mathrm{g})$, cream $40 \mathrm{~g}$ & Sulfathiazolum natricum & 4 \\
\hline Gentamicin WZF 0,3\%, krople do oczu, $5 \mathrm{ml} /$ Gentamicin WZF 0,3\%, eye drops, $5 \mathrm{ml}$ & Gentamicini sulfas & 1 \\
\hline Ketonal $100 \mathrm{mg} / 2 \mathrm{ml}$, roztw. do wstrz. $10 \mathrm{amp} /$ Ketonal $100 \mathrm{mg} / 2 \mathrm{ml}$, injection solution. $10 \mathrm{amp}$ & Ketoprofenum & 2 \\
\hline $\begin{array}{l}\text { Morphini sulfas WZF } 10 \mathrm{mg} / \mathrm{ml}, 1 \mathrm{ml} \text {, roztw. do wstrz. } 10 \mathrm{amp} / \text { Morphini sulfas WZF } 10 \mathrm{mg} / \mathrm{ml} \text {, } \\
\qquad 1 \mathrm{ml} \text {, injection solution, } 10 \mathrm{amp}\end{array}$ & Morphini sulfas & 1 \\
\hline Tramal $100 \mathrm{mg} / 2 \mathrm{ml}$, roztw. do wstrz., 5 amp./Tramal $100 \mathrm{mg} / 2 \mathrm{ml}$, injection solution, $5 \mathrm{amp}$. & Tramadoli hydrochloridum & 1 \\
\hline Pyralgin $0,5 \mathrm{~g} / \mathrm{ml}, 2 \mathrm{ml}$, roztw. do wstrz., 5 amp./Pyralgin $0,5 \mathrm{~g} / \mathrm{ml}, 2 \mathrm{ml}$, injection solution, 5 amp. & Metamizolum natricum & 1 \\
\hline Pyralgin $0,5 \mathrm{~g} / \mathrm{ml}, 5 \mathrm{ml}$, roztw. do wstrz., 5 amp./Pyralgin $0,5 \mathrm{~g} / \mathrm{ml}, 5 \mathrm{ml}$, injection solution, $5 \mathrm{amp}$. & Metamizolum natricum & 2 \\
\hline Majamil prolong. 100 mg, tabl. powl. 20 szt./Majamil prolong. 100 mg, coated tablets, 20 pcs. & Diclofenacum natricum & 1 \\
\hline 0,9\% NaCl, 10 ml, inj., 100 amp./0,9\% NaCl, 10 ml, inj., 100 amp. & Natrium chloratum & 1 \\
\hline 0,9\% NaCl, $100 \mathrm{ml}$, inj./0,9\% NaCl, $100 \mathrm{ml}$, inj. & Natrium chloratum & 10 \\
\hline 0,9\% NaCl, $500 \mathrm{ml}$, inj./0,9\% NaCl, $500 \mathrm{ml}$, inj. & Natrium chloratum & 20 \\
\hline Płyn fizjologiczny wieloelektrolitowy $500 \mathrm{ml}$, inj./Multielectrolyte saline solution $500 \mathrm{ml}$, inj. & Fluid infusione & 20 \\
\hline Sulfacetamidum Natr. $10 \%, 0,5 \mathrm{ml}$, krople 12 szt./Sulfacetamidum Natr. $10 \%, 0,5 \mathrm{ml}$, drops, 12 pcs & Sulfacetamidum Natricum & 2 \\
\hline Tribiotic, maść, antyb., $1 \mathrm{~g}, 10$ saszet./Tribiotic, antibiotic ointment, $1 \mathrm{~g}, 10$ sachets & Bacitracinum, Neomycinum, Polymyxinum B & 1 \\
\hline Woda utleniona $3 \% ., 100$ g./Hydrogen peroxide $3 \% ., 100 \mathrm{~g}$. & Hydrogen peroxide & 10 \\
\hline
\end{tabular}

Source: Own elaboration.

Źródło: Opracowanie własne.

W drugim dniu działań dowództwo komponentu medycznego spotkało się z przedstawicielką Międzynarodowej Federacji Czerwonego Krzyża (IFRC) i przedstawicielem Japońskiej
On day two of the operation, the medical team management met a representative of the International Federation of Red Cross (IFRC) and a representative of the Japan International Cooper- 
Organizacji Pomocy Humanitarnej (JICA). Podczas spotkania ustalono, że ze względu na kończący się zapas leków, jakim dysponował komponent medyczny, dalszą opiekę nad poszkodowanymi, po przekazaniu przez HUSAR Poland kopii kart udzielonej pomocy (ryc. 8), przejmie personel szpitala polowego z JICA.

\section{Podsumowanie i wnioski}

Ze względu na fakt, że statystyczna przeżywalność pod gruzami drastycznie maleje po 72-96 godzinach od trzęsienia, certyfikowane według INSARAG grupy poszukiwawczo-ratownicze są zobowiązane dotrzeć do kraju wzywającego pomocy w możliwie najkrótszym czasie. W tym celu wykorzystywany jest transport lotniczy. Zniszczenie infrastruktury w wyniku trzęsienia ziemi, w tym także medycznej, powoduje, że mieszkańcy dotkniętego katastrofą rejonu pozostają bez opieki medycznej zarówno tej podstawowej, jak i specjalistycznej.

Dlatego można wnioskować, że wysoka mobilność certyfikowanych wg. INSARAG grup poszukiwawczo-ratowniczych pozwala, w szczególności w początkowej fazie ratowniczej, realizować aspekt ratownictwa medycznego. Między innymi o tym mówi polityka INSARAG dot. działań „poza gruzami - beyound the rubble". Ratownicy medyczni w Grupie HUSAR koncentrują się na działaniach samej Grupy, jak i wstępnym zabezpieczeniu poszkodowanych wydobytych z gruzowisk. Gdy kończy się faza ratownicza i zaczyna się humanitarne wydobywanie zwłok oraz stabilizacja konstrukcji, wówczas szczególnie uwidacznia się "luka" opieki medycznej i przestrzeń do realizacji działań wydzielonego komponentu medycznego GPR. Do tego czasu i uzyskania pomocy medycznej osoby dotknięte trzęsieniem często zostają pod opieką rodzin, ale nie mają zapewnionej kwalifikowanej opieki medycznej.

Na podstawie doświadczeń z Haiti oraz Nepalu można również wnioskować, że w przyszłości, podczas zagranicznej akcji HUSAR, istotnym zadaniem powinno być wydzielenie komponentu medycznego grupy na końcu fazy ratowniczej. Powinno to spowodować, że "luka" braku opieki medycznej byłaby jak najkrótsza do czasu, gdy pieczę nad poszkodowanymi mogą przejąć odtworzone służby lokalne lub organizacje, których głównym zadaniem jest opieka medyczna (np. przybywające kilka dni później niż GPR tzw. zagraniczne zespoły medyczne - Foreign Medical Teams) [9]. Zasadne jest także twierdzenie, że po doposażeniu osobowym i sprzętowym wydzielony komponent medyczny HUSAR Poland byłby w stanie realizować zadania zbieżne do przewidzianych przez Światową Organizację Zdrowia dla zagranicznych zespołów medycznych typu pierwszego "Foreign Medical Team type 1" , aż do czasu ich przybycia na miejsce zdarzenia. ation Agency (JICA). During the meeting, it was decided that, because of the dwindling medication supplies available to the medical team, the personnel of the JICA field hospital would take over the patients from HUSAR Poland as it provides JICA with copies of patient reports (Fig. 8).

\section{Summary and conclusions}

Due to the fact that, statistically, the survival rates for victims trapped under rubble decrease dignificantly after 72-96 hours from an earthquake, INSARAG-certified search \& rescue groups are required to arrive at the affected country as soon as possible. As a result, such teams are deployed by air transport. Since infrastructure, including medical facilities, is often damaged as a result of the earthquake, people living in areas affected by the disaster remain without medical care, both primary and secondary.

Consequently, highly mobile INSARAG-certified search $\&$ rescue teams accommodate this need for medical rescue, especially during the initial phases of rescue operations. This issue is addressed, for example, in the INSARAG policy for beyond the rubble relief operations. HUSAR Group medical rescuers focus on their relevant Group roles, and on providing first aid to victims recovered from the ruins. When the rescue phase is completed, and the humanitarian recovery of bodies and building structure stabilisation begins, the gap in medical assistance becomes particularly evident, and S\&R groups can step in to fulfil this role. Before the provision of professional medical care is possible, earthquake victims often receive support from their families, but are not provided qualified medical aid.

Our Haiti and Nepal experiences have shown that in future international operations of HUSAR Poland, the optimum approach will be to deploy its medical team at the end of the rescue phase. This should narrow the gap in medical assistance until reconstructed local services or organisations (such as Foreign Medical Teams, which arrive several days after search $\&$ rescue teams), whose primary objective is to provide medical assistance, can take over the care of the victims [9]. In addition, it seems reasonable to argue that, provided with additional personnel and equipment, the deployed medical component of HUSAR Poland could serve roles similar to those defined by the World Health Organisation for Foreign Medical Teams Type 1 , until such teams arrive on site. 


\section{OCENA PACJENTA}

(Casualty assessment)

\begin{tabular}{|l|l|l|l|}
\hline $\begin{array}{l}\text { Imię i Nazwisko: } \\
\text { Name }\end{array}$ & $\begin{array}{l}\text { Data: } \\
\text { Date }\end{array}$ & $\begin{array}{l}\text { Godzina: } \\
\text { Time }\end{array}$ \\
\hline $\begin{array}{l}\text { Kobieta / Mężczyzna } \\
\text { Female/Male }\end{array}$ & $\begin{array}{l}\text { Wiek: } \\
\text { Age }\end{array}$ & $\begin{array}{l}\text { Numer dokumentu (paszport itp.): } \\
\text { Casualty ID }\end{array}$ \\
\hline $\begin{array}{l}\text { Lokalizacja: } \\
\text { Location }\end{array}$ & $\begin{array}{l}\text { Wywiad (Interview): } \\
\text { S (Symptoms): }\end{array}$
\end{tabular}

A (Allergies):

$\mathbf{M}$ (Medicines):

P (Past medical history):

L (Last oral intake):

$\mathbf{E}$ (Events leading up to the injury and/or illness):

$\mathbf{A}=$ otarcie (abrasion)

$\mathbf{B}=$ oparzenie (burn)

C = stłuczenie (contusion)

D = zwichnięcie (dislocation)

$\mathbf{F}=$ złamanie (fracture)

$\mathbf{H}=$ krwotok (haemorrhage)

$\mathbf{P}=$ ból (pain)

$\mathbf{R}$ = wzmożone napięcie mięśniowe (rigidity)

$\mathbf{S}=$ obrzęk (swelling)

Am = amputacja (amputation)

Co $=$ ciało obce (foregin body)

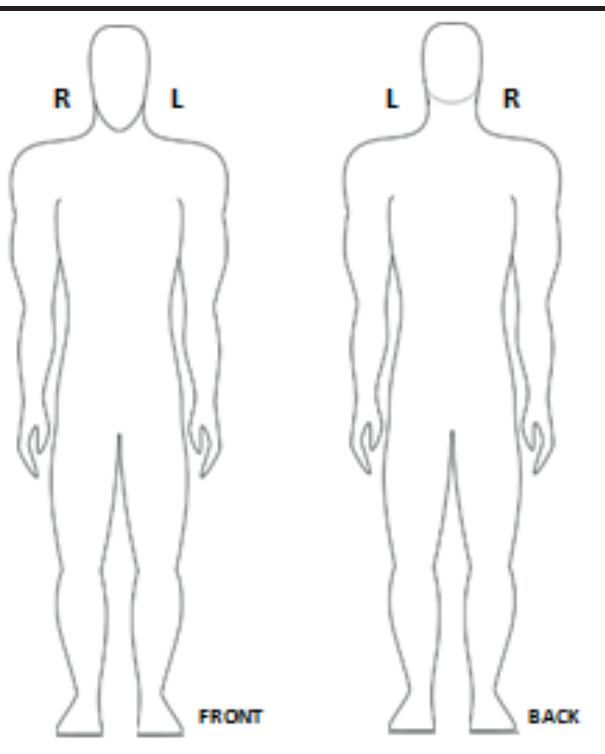

Temperatura ciała: Body temp.
Źrenice: $\quad$ równe $\square$ Pupils (equal)

okrągłe $\square$

(round) prawidłowa reakcja na światło $\square$ (reactive to light)

brak prawidłowej reakcji na światło $\square$ (non-reactive to light) 
Skala wczesnego ostrzegania (Early Warning Score - EWS)

\begin{tabular}{|c|c|c|c|c|c|c|c|}
\hline \multirow{2}{*}{$\begin{array}{l}\text { Parametry } \\
\text { (parameters) }\end{array}$} & \multicolumn{7}{|c|}{ Wyniki w punktach (results points) } \\
\hline & 3 & 2 & 1 & 0 & 1 & 2 & 3 \\
\hline Tętno (pulse) & & $<40$ & $41-50$ & $51-90$ & $91-110$ & $111-130$ & $>131$ \\
\hline $\begin{array}{l}\text { Częstość oddechów } \\
\text { (respirations) }\end{array}$ & $<8$ & & $9-11$ & $12-20$ & & $21-24$ & $>25$ \\
\hline $\begin{array}{l}\text { Temperatura ciała } \\
\text { (body temp.) }\end{array}$ & $<35,0$ & & $35,1-36,0$ & $36,1-38,0$ & $38,1-39,0$ & $>39,1$ & \\
\hline $\begin{array}{l}\text { RR skurczowe } \\
\text { (blood pressure) }\end{array}$ & $<90$ & $91-100$ & $101-110$ & 111-199 & & $>200$ & \\
\hline $\begin{array}{l}\text { Saturacja } \\
\text { (saturation) }\end{array}$ & $<91$ & $92-93$ & $94-95$ & $>96$ & & & \\
\hline AVPU & & & & A & $\mathbf{V}$ & $\mathbf{P}$ & $\mathbf{U}$ \\
\hline $\begin{array}{l}\begin{array}{l}\text { Diureza } \\
\text { (diuresis) }\end{array} \\
\end{array}$ & $<10 \mathrm{ml} / \mathrm{h}$ & $<0,5 \mathrm{ml} / \mathrm{kgm} . \mathrm{c} . \mathrm{h}$ & & $>0,5 \mathrm{ml} / \mathrm{kgm} . \mathrm{c} . / \mathrm{h}$ & & & \\
\hline
\end{tabular}

\begin{tabular}{|c|c|c|c|}
\hline \multirow{2}{*}{$\begin{array}{l}\text { Punktacja } \\
\text { (points) }\end{array}$} & \multirow{2}{*}{$\begin{array}{l}\text { Minimalny odstẹp między } \\
\text { obserwacjami } \\
\text { (Minimum observation } \\
\text { interval) }\end{array}$} & \multicolumn{2}{|r|}{ Zadania (tasks) } \\
\hline & & $\begin{array}{l}\text { Ratownik medyczny/pielęgniarka } \\
\text { (Medical rescuer/nurse) }\end{array}$ & $\begin{array}{l}\text { Lekarz } \\
\text { (Doctor) }\end{array}$ \\
\hline $3-5$ & $\begin{array}{l}\text { Co } 4 \text { godziny } \\
\text { (every } 4 \text { hours) }\end{array}$ & $\begin{array}{l}\text { Kontrola parametrów } \\
\text { (parameter check) }\end{array}$ & \\
\hline 6 & $\begin{array}{l}\text { Co } 4 \text { godziny } \\
\text { (every } 4 \text { hours) }\end{array}$ & $\begin{array}{c}\text { Wezwać lekarza } \\
\text { (call the doctor) }\end{array}$ & $\begin{array}{l}\text { Badanie lekarskie w ciągu } 1 \text { godziny } \\
\text { (medical checkup in } 1 \text { hour) }\end{array}$ \\
\hline $7-8$ & $\begin{array}{l}\text { Co } 1 \text { godzinę } \\
\text { (every } 1 \text { hour) }\end{array}$ & $\begin{array}{l}\text { Wezwać lekarza. Podłączyć monitor na stałe } \\
\text { (call the doctor, begin continuous monitoring) }\end{array}$ & $\begin{array}{c}\text { Badanie lekarskie w ciagu } 30 \text { minut } \\
\text { (medical checkup in } 30 \text { minutes) }\end{array}$ \\
\hline$>9$ & $\begin{array}{c}\text { Co } 30 \text { minut } \\
\text { (every } 30 \text { minutes) }\end{array}$ & $\begin{array}{l}\text { Wezwać lekarza. Podłączyć monitor na stałe } \\
\text { (call the doctor, begin continuous monitoring) }\end{array}$ & $\begin{array}{c}\text { Badanie lekarskie w ciągu } 15 \text { minut. Wezwanie anestezjologa, } \\
\text { ponieważ poszkodowany prawdopodobnie wymaga leczenia na OIT } \\
\text { (Medical checkup in } 15 \text { minutes. Call an anaesthesiologist, as the injured } \\
\text { probably needs treatment at the ICU) }\end{array}$ \\
\hline
\end{tabular}

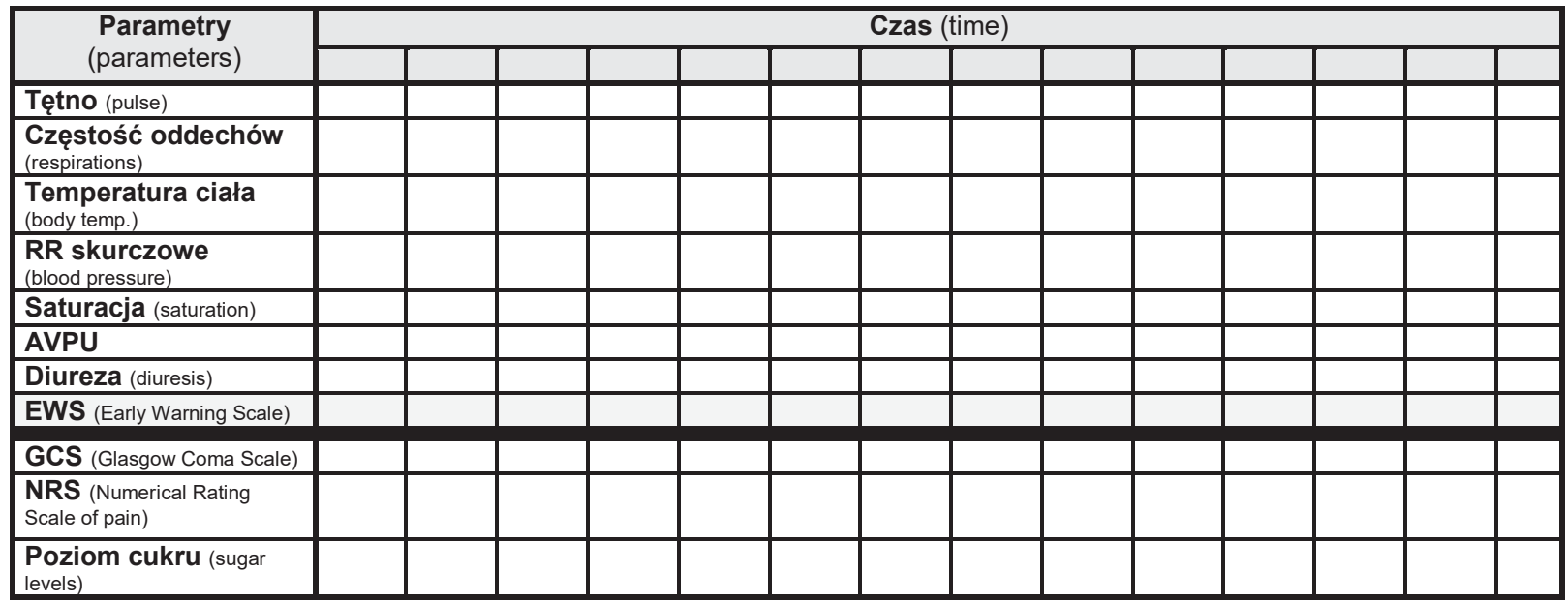

Leczenie i podane leki (treatment \& meds. given):

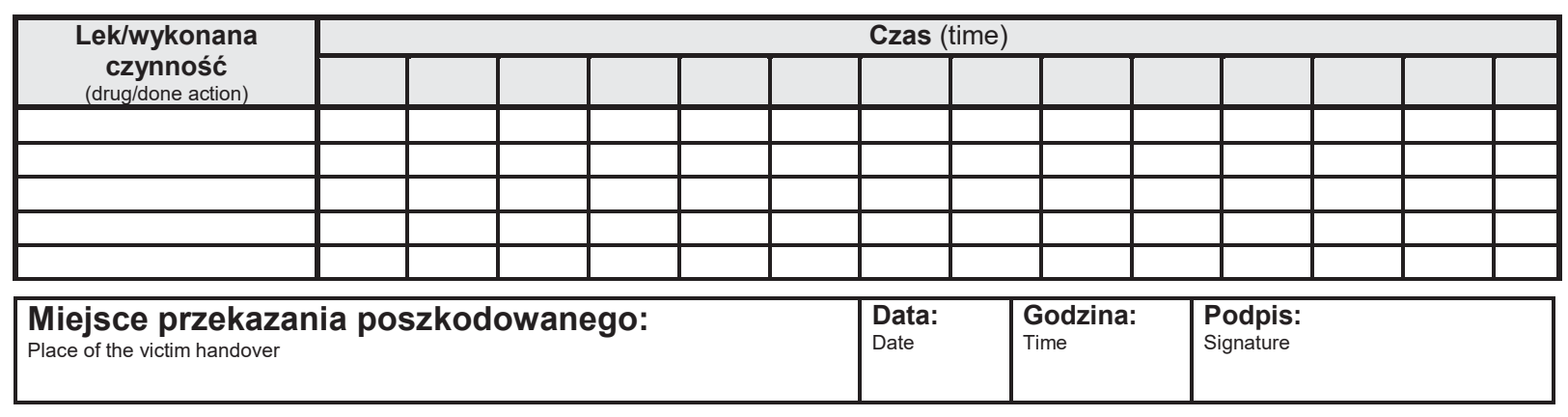

Rycina 8. Karta oceny poszkodowanego HUSAR Poland

Figure 8. Victim assessment card used by HUSAR Poland

Source: Own elaboration.

Źródło: Opracowanie własne. 


\section{Literatura/Literature}

[1] Decyzja Nr 47 Komendanta Głównego Państwowej Straży Pożarnej z dnia 26 września 2017 r. zmieniająca Decyzję Nr 46/2009 Komendanta Głównego Państwowej Straży Pożarnej z dnia 24 listopada 2009 r. w sprawie wyznaczenia strażaków Państwowej Straży Pożarnej do składu grupy USAR Poland przygotowującej do udziału w działaniach poszukiwawczo-ratowniczych i ćwiczeniach poza granicami państwa oraz wyznaczenia strażaków Państwowej Straży Pożarnej do udziału w działaniach transgranicznych prowadzonych wspólnie z pododdziałami Centralnego Odwodu Operacyjnego.

[2] Rozkaz nr 8 Komendanta Głównego Państwowej Straży Pożarnej z dnia 27 marca 2014 r. w sprawie organizacji ćwiczenia recertyfikującego Polską Ciężką Grupę Poszukiwawczo-Ratowniczą "IER 2014" przez ekspertów Międzynarodowej Grupy Doradczej ds. Poszukiwań i Ratownictwa (INSARAG) USAR Poland.

[3] Feltynowski M., Przygotowanie Grupy Poszukiwawczo-Ratowniczej Państwowej Straży Pożarnej do działań międzynarodowych, rozprawa doktorska, AON 2016.
[4] Oficjalna strona internetowa INSARAG, www.insarag.org.- [dostęp: 14.04.2018]

[5] Zasady organizacji działań poszukiwawczo-ratowniczego w krajowym systemie ratowniczo-gaśniczym, KG PSP, Warszawa, 2011 z późn. zm.

[6] Nepal earthquake 2015 - Grade 3 emergency,http://www.who.int/ emergencies/nepal/en/ [dostęp: 20.06.2018].

[7] Feltynowski M., Kopczyński M., Sprawozdanie ze służbowego wyjazdu zagranicznego z akcji GPR "Nepal 2015", KG PSP, Warszawa 2015.

[8] Decyzja Małopolskiego Wojewódzkiego Inspektora Farmaceutycznego w Krakowie z dnia 19.12. 2013 r wyrażająca zgodę na posiadanie przez SA PSP w Krakowie w celach medycznych preparatów zawierających w swoim składzie środki odurzające lub psychotropowe (FAKR - 1.857.1.214.2013).

[9] Norton I., Von Schreeb J., Aitken P., Herard P., Lajolo C., Classification and minimum standards for foreign medical teams in sudden onset disasters ,World Health Organisation, Global Health Claster 2013, 27-28.
BRYG. DR N. MED. MARIUSZ CHOMONCIK - ukończył Akademię Medyczną w Białymstoku. Jest specjalistą anestezjologii i intensywnej terapii, koordynatorem ratownictwa medycznego w Szkole Aspirantów Państwowej Straży Pożarnej w Krakowie. Ponadto pracuje jako wykładowca w Państwowej Wyższej Szkole Zawodowej w Nowym Sączu. Podczas Światowych Dni Młodzieży był dowódcą Komponentu Medycznego PSP.

BRYG. LEK. LESZEK SMOLARCZYK - ukończył Akademię Medyczną w Krakowie. Jest lekarzem systemu, koordynatorem ratownictwa medycznego służby PSP.

BRYG. DR INŻ. MARIUSZ FELTYNOWSKI - kierownik Centrum Systemów Bezzałogowych i Autonomicznych - Centrum Dronów. Od 2016 r. kierownik Działu Samodzielnych Ekspertów w Centrum Naukowo-Badawczym Ochrony Przeciwpożarowej im. Józefa Tuliszkowskiego w Józefowie. W 2016 r. ukończył studia III stopnia na Wydziale Zarządzania i Dowodzenia, Akademii Obrony Narodowej, uzyskując stopień naukowy doktora w dziedzinie nauk społecznych. Specjalista w zakresie działań ratowniczych, w tym zwłaszcza problematyki działań i funkcjonowania specjalistycznych grup poszukiwawczo-ratowniczych kierowanych do działań po katastrofach budowlanych i trzęsieniach ziemi.
BRIGADIER MARIUSZ CHOMONCIK, MD, PH.D. - he graduated from the Medical University of Białystok. He specialises in anaesthesiology and intensive therapy and coordinates medical rescue operations at the School of State Fire Service in Kraków. He also works as a lecturer at the State University of Applied Sciences in Nowy Sącz. During the World Youth Day he headed the Medical Component of the State Fire Service (PSP).

BRIGADIER LESZEK SMOLARCZYK, MD - he graduated from the Jagiellonian University Medical College. He is a physician working under.

BRIG. ENG. MARIUSZ FELTYNOWSKI, PH.D. - manager of the Drone Centre - Centre for Unmanned and Autonomous Systems. Since 2017 manager of the Department of Independent Experts of the Scientific and Research Centre for Fire Protection - National Research Institute in Józefów. In 2016 he completed his doctoral studies at the Faculty of Management and Command of the National Defence University of Warsaw, obtaining the title of Doctor of Social Sciences. Specialist in the field of rescue operations, particularly issues related to the operations and functioning of specialised search-andrescue teams deployed in the aftermath of construction accidents and earthquakes. 